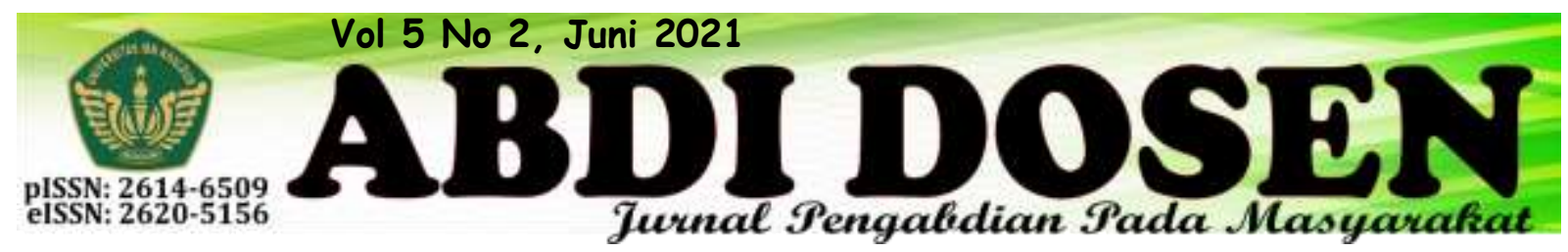

\title{
SOSIALISASI MODEL MANAJEMEN PENDIDIKAN BERBASIS MASYARAKAT DI PONDOK PESANTREN SYEKH QURO KABUPATEN KARAWANG
}

\author{
Undang Ruslan Wahyudin ${ }^{1}$, Hinggil Permana ${ }^{2}$, Ella Nurlailasari ${ }^{3}$ dan Taufik Mustofa ${ }^{4}$ \\ urwahyudin@fai.unsika.ac.id ${ }^{1}$, hinggil.permana@fai.unsika.ac.id ${ }^{2}$, ella.nurlailasari@fikes.unsika.ac.id ${ }^{3}$, \\ taufik.mustofa@fai.unsika.ac.id ${ }^{4}$ \\ Universitas Singaperbangsa Karawang ${ }^{1,2,3,4}$
}

\begin{abstract}
This community service is one form of the tri darma of higher education. The purpose of this service is to socialize a community-based education management model. The parties involved as partners in this activity are educational institutions in the form of Islamic boarding schools, because Islamic boarding schools are a form of educational institutions that can be assumed as a community-based education model. Karawang Regency has an Islamic boarding school which is categorized as one of the oldest Islamic boarding schools in Java, namely the Syekh Quro Islamic Boarding School. This pesantren was founded by Syekh Hasanudin or Syekh Quro in 1340 Saka (1418 AD) at Bunut Kertayasa Port, West Karawang. The reality that occurs in the field related to community-based education management in these Islamic boarding schools is still far from expectations. This is due to the lack of understanding of the community-based education management model and lack of collaboration between stakeholders. The method used in this community service is lectures and questions and answers which are held in the form of limited direct seminars due to the Covid-19 pandemic. The targets of this community service are the managers and teachers of the pesantren, community leaders and community representatives around the boarding school. Through this PKM activity, it is hoped that the management of Islamic boarding schools will better understand the community-based education management model so that it can be implemented in the implementation of education with the aim of producing superior HR products at the Syekh Quro Islamic boarding school, Karawang.
\end{abstract}

Keywords: Management, Community Based Education, Syekh Quro Islamic Boarding School

\begin{abstract}
ABSTRAK
Pengabdian kepada masyarakat ini merupakan salah satu bentuk tri darma perguruan tinggi. Tujuan pengabdian ini adalah untuk mensosialisasikan model manajemen pendidikan yang berbasis masyarakat. Pihak yang dilibatkan sebagai mitra dalam kegiatan ini ialah lembaga pendidikan yang berbentuk pesantren, karena pondok pesantren merupakan bentuk lembaga pendidikan yang dapat diasumsikan sebagai model pendidikan berbasis masyarakat. Kabupaten karawang mempunyai pesantren yang dikategorikan sebagai salah satu pesantren tertua di Jawa, yaitu Pondok Pesantren Syekh Quro. Pesantren ini didirikan oleh Syekh Hasanudin atau Syekh Quro pada tahun 1340 Saka (1418 M) di Pelabuhan Bunut Kertayasa, Karawang Barat. Realitas
\end{abstract}


yang terjadi di lapangan berkaitan dengan manajemen Pendidikan berbasis masayarakat di pondok pesantren tersebut masih jauh dari harapan. Hal ini disebabkan oleh belum dipahaminya model manajemen pendidikan berbasis masyarakat dan kurang kolaborasi antar pemangku kepentingan. Metode yang digunakan dalam pengabdian kepada masyarakat ini ialah ceramah dan tanya jawab yang diselenggarakan dalam bentuk seminar langsung terbatas dikarenakan pandemic covid-19. Sasaran dalam pengabdian kepada masyarakat ini ialah para pengelola dan pengajar pesantren, tokoh masyarakat dan perwakilan masyarakat di sekitar pondok pesantren. Melalui kegiatan PKM ini diharapkan para pengelola pondok pesantren lebih memahami model manajemen Pendidikan berbasis masyarakat sehingga dapat diiplementasikan dalam penyelenggaraan pendidikan dengan tujuan menghasilkan produk SDM unggul di pondok pesantren Syekh Quro, Karawang.

Kata Kunci : Manajemen, Pendidikan Berbasis Masyarakat, Pondok Pesantren Syekh Quro

\section{PENDAHULUAN}

Dalam Kamus Besar Bahasa Indonesia (197:623) kata manajemen diartikan sebagai proses penggunaan sumber daya secara efektif untuk mencapai sasaran. Sadili Samsudin (2005:15) mendefinisikan kata manajemen berasal dari Bahasa Inggris yaitu management yang dikembangkan dari kata to manage, yang artinya mengatur atau mengelola.

Dalam konteks pendidikan, Made Pidarta sebagaimana dikutip oleh Sulistyorini (2009:13) mengemukakan bahwa manajemen pendidikan adalah aktivitas memadukan sumber-sumber pendidikan agar terpusat dalam usaha untuk mencapai tujuan pendidikan yang telah ditentukan sebelumnya. Menurut Husain Usman (2013:6) manajemen Pendidikan meliputi: perencanaan program sekolah/madrasah, pelaksanaan program sekolah/madrasah, kepemimpinan kepala sekolah/madrasah, pengawas/evaluasi, dan sistem informasi sekolah/madrasah.

Menurut Sulistyorini (2009:75) pendidikan berbasis masyarakat merupakan model pengelolaan pendidikan yang menempatkan peran masyarakat (community roles) pada posisi otonom untuk menentukan, mengatur, dan menyelenggarakan pendidikan sesuai aspirasi dan kebutuhannya. Sedangkan menurut Nurhattati Fuad (2014:176) Pendidikan berbasis masyarakat dapat merujuk pada pengertian jika sesuatu berbasis masyarakat maka sesuatu itu menjadi milik masyarakat. Kepemilikan mengimplikasikan adanya pengendalian secara penuh terhadap pengambilan keputusan. Kepemilikan penuh berarti bahwa masyarakat memutuskan tujuan, sasaran, pembiayaan, kurikulum, standard ujian, guru dan klasifikasinya, persyaratan siswa dan sebagainya. Pendidikan berbasis masyarakat menekankan pentingnya pemahaman akan kebutuhan masyarakat dan cara pemecahan masalah oleh masyarakat dengan menggunakan potensi yang ada di masyarakat.

Dari berbagai pendapat para ahli di atas, maka dapat disimpulkan bahwa manajemen pendidikan berbasis masyarakat bisa diartikan sebagai proses perencanaan, pengorganisasian, pemimpinan, dan pengendalian semua sumber, personil, dan materil di lembaga pendidikan yang berbasiskan atau melibatkan partisipasi masyarakat. 
Berkaitan dengan kebijakan yang dicanangkan oleh pemerintah tentang otonomi pendidikan yang berkaitan dengan pendidikan berbasis masyarakat, pondok pesantren dapat diasumsikan sebagai bentuk lembaga pendidikan yang menerapkan model pendidikan berbasis masyarakat . Pondok pesantren adalah lembaga pendidikan yang tumbuh dan berkembang dari, oleh, dan untuk masyarakat. Pondok pesantren juga merupakan lembaga pendidikan Islam yang indigenous, yang hingga kini mandiri dan memberdayakan masyarakat. Bahkan menurut pengamatan Bernardin (2007) Pesantren merupakan satu-satunya pendidikan yang sepenuhnya communitybased.

Pesantren sebagai lembaga pendidikan berbasis masyarakat, dengan jumlah pesantren dan santri yang demikian banyak dituntut untuk dapat menjawab kebutuhan masyarakat seiring dengan tuntutan perubahan zaman, sehingga dibutuhkan manajemen dan tata kelola sistem pendidikan yang baik sehingga menghasilkan tata kelola yang baik dalam upaya meningkatkan mutu manajemen (tata kelola) pesantren ke arah yang lebih baik. Kabupaten karawang dikenal sebagai wilayah yang mempunyai banyak pesantren, salah satunya dikategorikan sebagai pesantren tertua di Jawa, yaitu Pondok Pesantren Syekh Quro. Pesantren ini didirikan oleh Syekh Hasanudin atau Syekh Quro pada tahun 1340 Saka (1418 M) di Pelabuhan Bunut Kertayasa, Karawang Barat. Pada kenyataannya di lapangan untuk menghasilkan SDM yang unggul tersebut masih menghadapi banyak permasalahan, terlebih lagi untuk lembaga pendidikan yang berbasis masyarakat yaitu pondok pesantren yang tanpa banyak campur tangan pemerintah. Pada umumnya jenis pondok pesantren seperti ini menerapkan penyelenggaraan pendidikan dengan Prinsip kekeluargaan (kinship system) dan profesionalisme dipergunakan dalam penetapan kepengurusan pondok pesantren ini. Dengan kata lain, prinsip familiisme dipergunakan dalam penetapan struktur organisasi dan penetapan fungsionaris yang mendudukinya. Model penyelenggaraan pendidikan pondok pesantren berbasis keluarga-seperti diterapkan di pondok pesantren Syekh Quro khususnya dan di sebagian besar pontren Indonesia umumnya, secara sosiokultural, cenderung dapat dipertahankan keberadaannya di masa depan. Daya resistensi model "family-business" (al Syuhlu al 'Aailah) yang diterapkan pondok pesantren Syekh Quro dan sebagian besar pondok pesantren di Indonesia digolongkan sangat tinggi. Penerapan model penyelenggaraan pendidikan seperti ini sebenarnya tidak salah akan tetapi dipandang dari sisi manajemen memiliki kekurangan yaitu rendahnya partisipasi masyarakat untuk ikut berpartisipasi aktif dalam proses penyelenggaraan pendidikan berdasarkan kebutuhan masyarakat. Hal ini disebabkan kurang pahamnya pengelola lembaga pendidikan dalam membuat model Manajemen Pendidikan Berbasis Masyarakat. Selain itu masalah lainnya adalah para pengelola pendidikan mengalami kesulitan dalam mengimplementasikan model manajemen pendidikan berbasis masayarakat.

Berdasarkan hasil analisis permasalahan mitra di atas, maka para pengelola Lembaga pendidikan membutuhkan pemahaman tentang model manajemen pendidikan berbasis masyarakat terutama bagi pengelola pendidikan di lembaga pendidikan dalam bentuk pesantren. Salah satu upaya yang 
dapat dilakukan untuk mengenalkan dan meningkatkan pengetahuan serta pemahaman terkait model pendidikan berbasis masyarakat bagi para pengelola pendidikan yaitu dengan sosialisasi model manajemen pendidikan berbasis

\section{METODE PELAKSANAAN}

Metode yang digunakan dalam kegiatan pengabdian kepada masyarakat ini ialah dengan metode ceramah dan tanya jawab yang diselenggarakan dalam bentuk seminar terbatas dengan menerapkan protokol kesehatan yang ketat dikarenakan situasi pandemic covid-19. Program pengabdian kepada masyarakat dilaksanakan dalam bentuk sosialisasi berupa pemamparan materi kepada mitra terkait permasalahan yang dihadapi mitra yaitu kurangnya pemahaman para pengelola pondok pesantren berkaitan dengan model manajemen Pendidikan berbasis masyarakat. Materi yang akan disampaikan diharapkan dapat memberikan peningkatan pengetahuan dan pemahaman untuk

\section{HASIL DAN PEMBAHASAN}

Hasil dan luaran pada pemaparan materi pertama mengenai pengenalan Konsep Dasar Manajemen Pendidikan Berbasis Masyarakat yang disampaikan oleh Hinggil Permana, S.Pd., M.Pd dijelaskan sebagai berikut :

a. Pada tahap awal dilakukan apersepsi untuk mengetahui dan menggali pengetahuan awal para peserta tentang pengetahuan dan pemahaman Manajemen Pendidikan Berbasis Masyarakat. Hasilnya menunjukkan bahwa mayoritas peserta belum terlalu memahami tentang konsep dasar Manajemen Pendidikan Berbasis Masyarakat. masyarakat. Hal ini sangat perlu dilaksanakan karena mayoritas pengelola pondok pesantren belum faham tentang manajemen pendidikan berbasis masyarakat baik dari segi konsep maupun implementasinya.

selanjutnya dapat diterapkan oleh mitra dalam kegiatan penyelenggaraan pendidikan. Adapun materi yang akan disampaikan pada mitra meliputi :

a. Konsep Dasar Manajemen Pendidikan Berbasis Masyarakat

b. Implementasi Manajemen Pendidikan Berbasis Masyarakat

c. Evaluasi Kegiatan Pengabdian kepada Masyarakat (PkM)

Sasaran pengabdian kepada masyarakat ini adalah pengelola pondok pesantren Syekh Quro Kabupaten Karawang yang terdiri dari pimpinan pondok pesantren, para pengajar, tokoh masyarakat dan perwakilan masyarakat sekitar pondok pesantren.

b. Tahap selanjutnya pemateri memaparkan hal-hal yang berkaitan dengan konsep dasar Manajemen Pendidikan Berbasis Masyarakat, meliputi: Pengertian Manajemen Pendidikan Berbasis Masyarakat, Dimensi Manajemen Pendidikan Berbasis Masyarakat, Tujuan Pendidikan Berbasis Masyarakat, Prinsip Pendidikan Berbasis Masyarakat, Kurikulum Pendidikan Berbasis Masyarakat dan Model Pendidikan Berbasis Msyarakat.

c. Setelah materi disampaikan, para peserta antusias menyampaikan berbagai pertanyaan. Mayoritas 
pertanyaan berfokus pada kontribusi nyata masyarakat dalam penyusunan Kurikulum Pendidikan Berbasis Masyarakat.

Hasil dan luaran pada pemaparan materi kedua mengenai pengenalan Implementasi Manajemen Pendidikan Berbasis Masyarakat yang disampaikan oleh Dr. Undang Ruslan Wahyudin, M.Pd dijelaskan sebagai berikut :

a. Pada tahap awal pemateri mereview kembali secara singkat tentang materi yang disampaikan pemateri pertama.

b. Tahap selanjutnya pemateri memaparkan hal-hal yang berkaitan dengan Implementasi Manajemen Pendidikan Berbasis Masyarakat, meliputi : Perencanaan Pendidikan Berbasis Masyarakat, Pengorganisasian Pendidikan Berbasis Masyarakat, Kepemimpinan dalam Pendidikan Berbasis Masyarakat, Pengawasan dalam Penyelenggaraan Pendidikan Berbasis Masyarakat dan Prinsipprinsip Implementasi Pendidikan Berbasis Masyarakat.

c. Setelah materi disampaikan, para peserta antusias mengajukan berbagai pertanyaan terkait Implementasi Manajemen Pendidikan Berbasis Masyarakat. Salah satu bahasan diskusi yang sangat menarik yaitu pertanyaan dari pimpinan pondok pesantren yang mencoba menggambarkan model manajemen pendidikan yang sudah diterapkan untuk diintegrasikan dalam manajemen pendidikan berbasis masyarakat. Diantaranya :

1) Dalam perencanaan, model manajemen tetap mempertahankan peran kyai dalam penyusunan visimisi dan tujuan pondok pesantren. Program pondok pesantren berorientasi pada kebutuhan masyarakat dan disusun merujuk pada visi-misi yang dikembangkan (para) pengelola dan pengajar di pondok pesantren Syekh Quro.

2) Penyusunan kurikulum pondok pesantren didasarkan pada partisipasi aktif dan kebutuhan masyarakat baik berupa pengetahuan maupun keterampilan yang ingin dihasilkan.

3) Dalam pengorganisasian, struktur, fungsi, dan pembagian tugas, serta rekruitmen SDM dapat didasarkan pada model "Community Bussines", artinya seluruh sumber daya yang ada di pondok pesantren dan masyarakat di sekitar pondok pesantren memiliki kesempatan untuk masuk dan terlibat langsung dalam penyelenggaraan Pendidikan sesuai keahlian yang dimiliki.

4) Dalam kepemimpinan, dapat dipergunakan pola/model kepemimpinan karismatikprofesional, artinya pimpinan pondok pesantren menjadi sentral dengan tetap mengutamakan kepentingan publik dalam pengambilan keputusan terkait pelaksanaan pendidikan di pondok pesantren.

5) Dalam pengendalian, kontrol internal berdasarkan prinsip-prinsip agama Islam dan trust dapat diterapkan dan kontrol eksternal yang diperoleh dari partisipasi aktif dari masyarakat sekitar pondok pesantren.

Hasil dan luaran pada pemaparan materi ketiga mengenai Evaluasi Kegiatan disampaikan oleh Ella Nurlailasari, S.H., M.H dijelaskan sebagai berikut : 
a. Pemateri membagikan kuesioner dalam bentuk googleform kepada para peserta terkait pelaksanaan program Pengabdian Kepada Masyarakat (PkM) ini untuk mengukur sejauh mana ketercapaian tujuan pelaksanaan Pengabdian Kepada Masyarakat (PkM).

b. Pemateri membagikan link googleform dan menjelaskan poin-poin penting yang terdapat di dalam kuesioner dan membimbing para peserta untuk memilih jawaban sesuai dengan pengetahuan akhir yang didapatkan.

c. Penyebaran kuesioner dilakukan secara langsung dengan cara menunggu responden saat pengisian kuesioner.

\section{KESIMPULAN}

Berdasarkan kegiatan yang telah dilaksanakan oleh Tim Pengabdian kepada Masyarakat $(\mathrm{PkM})$ di Pondok Pesantren Syekh Quro Kabupaten Karawang, dapat disimpulkan bahwa :

1. Pelaksanaan sosialisasi Manajemen Pendidikan Karakter Berbasis Masyarakat telah memenuhi luaran yang ditargetkan, yaitu terjadi peningkatan pemahaman mengenai Manajemen Pendidikan Karakter Berbasis Masyarakat, sehingga setelah sosialisasi diberikan, peserta dapat menjelaskan konsep dasar Manajemen Pendidikan Karakter Berbasis Masyarakat.

2. Kegiatan sosialisasi mengenai implementasi Manajemen Pendidikan Karakter Berbasis Masyarakat juga telah mencapai target luaran. Hal ini bisa dilihat dari rancangan awal manajemen Pendidikan berbasis masyarakat di
Keseluruhan luaran yang dihasilkan setelah dilaksanakan kegiatan sosialisasi ini dapat disimpulkan bahwa sebanyak $72 \%$ peserta memahami tentang konsep dasar Manajemen Pendidikan Berbasis Masyarakat dan sebanyak $64 \%$ memahami tentang Implementasi Manajemen Pendidikan Berbasis Masyarakat. Hasil ini menunjukkan tingkat ketercapaian kegiatan sosialisasi ini bisa dikategorikan berhasil karena lebih dari separuh peserta kegiatan telah memenuhi target dan mencapai tujuan dari pelaksanaan Pengabdian kepada Masyarakat (PkM) ini.

pondok pesantren syekh Quro dengngan mengintegrasikan manajemen pendidikan berbasis masayarakat dengan manajemen pendidikan yang telah diterapkan yang meliputi tahap perencanaan, penyusunan kurikulum, pengorganisasian, kepemimpinan dan pengendalian atau kontrol pelaksanaan pendidikan dengan melibatkan partisipasi aktif dari pihak masyarakat.

3. Keseluruhan luaran yang dihasilkan setelah dilaksanakan kegiatan sosialisasi ini dapat disimpulkan bahwa sebanyak $72 \%$ peserta memahami tentang konsep dasar Manajemen Pendidikan Berbasis Masyarakat dan sebanyak $64 \%$ memahami tentang Implementasi Manajemen Pendidikan Berbasis Masyarakat. 


\section{DAFTAR PUSTAKA}

Bernardin, H. J. 2007. Human Resource Management: An Experiential Approach. New York : Mc.Graw- Hill

Husain Usman. 2013. Manajemen (Teori, Praktek dan Riset Pendidikan), PT. Ikrar Mandiri Abadi : Jakarta.

Kamus Besar Bahasa Indonesia. 1997. Balai Pustaka : Jakarta.
Nurhattati Fuad. 2014. Manajemen Pendidikan Berbasiis Masyarakat, Konsep dan Strategi Implementasi, PT. Raja Grafindo Persada : Jakarta.

Sadili Samsudin. 2005. Manajemen Sumber Daya Manusia, CV. Pustaka Setia : Bandung.

Sulistyorini. 2009. Manajemen Pendidikan Islam; Konsep, Strategi dan Aplikasi, Penerbit Teras : Yogyakarta 